\title{
Sikap Terhadap Konsentrasi Belajar Siswa Pada Mata Pelajaran Fisika di Sekolah Menengah Atas
}

\author{
Tari Okta Puspitasari ${ }^{1 \star}$, Yolanda Eka Putri ${ }^{2}$, dan Yohanes ${ }^{3}$ \\ 1,2 Univrsitas Jambi, Jl. Lintas Sumatra Jambi-Ma. Bulian No.Km. 15, Mendalo Darat, Jambi, 36122 \\ ${ }^{3}$ STKIP YPM, Jl. Jendral Sudirman, Komplek STKIP, No. 16, Pematang Kandis, Bangko, Kab. Merangin, Jambi \\ 37313 \\ *E-mail: tarioktapuspitasari@gmail.com
}

\begin{abstract}
Abstrak
Tujuan dari penelitian ini adalah untuk mengerahui hubungan sikap terhadap konsentrasi belajar siswa pada mata pelajaran fisika. Metode penelitian yang digunakan adalah penelitian kuantitatif dengan desain asosiatif. Instrumen penelitian yang digunakan adalah angket. Teknik analisis data yang digunakan adalah analisis statistik deskriptif dan analisis inferensial. Statistik deskriptif yang digunakan adalah mean, median, mode, dan standar deviasi. Sedangkan statistic inferensial yang digunaan adalah uji kolerasional. Berdasarkan penelitian yang telah dilakukan, terdapat hubungan yang positif antara sikap dan konsentrasi pada mata pelajaran fisika di SMAN 8 Kota Jambi yang juga cukup kuat jika dilihat dari nilai sig yang dihasilkan, yaitu sebesar 0.04.
\end{abstract}

Kata kunci: belajar, fisika, konsentrasi, sikap.

\begin{abstract}
The purpose of this study is to explore the relationship between attitudes and student learning in physics. The research method used is quantitative research with associative design. The research instrument used was a questionnaire. The data analysis technique used is descriptive statistical analysis and inferential analysis. Descriptive statistics used are the mean, median, mode, and standard deviation. Whereas the inferential statistics that can be used is the collaborative test. Based on research that has been done, there is a positive relationship between attitude and concentration in physics at SMAN 8 Jambi City which is also quite strong when viewed from the sig value generated, which is equal to 0.04 .
\end{abstract}

Keywords: study, physics, concentration, attitude.

\section{PENDAHULUAN}

Belajar merupakan sebuah proses memperbaiki kualitas hidup manusia. Menurut Hanafy (2014) menjelaskan belajar merupakan kegiatan fisik maupun psikis yang menghasilkan perubahan tingkah laku individu dalam bentuk kemampuan yang relatif konstan. Siswa akan belajar untuk menambah pengetahuan dan pengetahuan untuk mendapatkan pendidikan yang sesuai dengan standar yang ada (Hubert, 2014). Kemampuan dan potensi diri yang ada pada manusia akan terasah dan dikembangkan sesuai dengan tingkat pendidikan yang mereka ikuti (Gougoulakis, 2017). Biasanya akan diasah sesuai dengan jenjang yang ditempuh. Dalam berbagai tingkatan tersebut, terdapat mata pelajaran yang mempelajari tentang alam, atau yang sering disebut dengan IImu Pengetahuan Alam.

IImu Pengetahuan Alam adalah proses pembelajaran yang sangat terkait dengan lingkungan dan keteraturan alam semesta yang diciptakan oleh Tuhan Yang Mahakuasa (Susilawati, Hemani, \& Sinaga. 2017). Program pendidikan sains yang kaya akan metode dan teknik pengajaran membuat siswa aktif dalam pengetahuan mereka, memungkinkan platform untuk diskusi dan mengarahkan siswa untuk berpikir dan menghasilkan pembelajaran yang efektif (Şener, Türk \& Taş. 2015). Ilmu Pengetahuan Alam sendiri memilki beberapa 
cabang diantaranya adalah mata pelajaran fisika. Pada pendidikan tingkat menengah atas, umumnya siswa masih menganggap fisika itu sulit (Pratama, Ermawati \& Hartini. 2017).

Fisika merupakan ilmu yang mempelajari tentang fenomena alam dan interaksi yang telah terjadi di dalamnya (Asih, 2017; Khoiri, Hindarto \& Sulhadi, 2011). Proses pembelajaran fisika juga lebih banyak tentang konsep yang konkret sampai pada abstrak (Siswanto, Kaniawati, \& Suhandi. 2014). Sehingga, fisika masih dianggap sulit oleh siswa, karena siswa diharuskan menghafal rumus yang abstrak (Astalini, Kurniawan \& Sumaryanti. 2018). Oleh karena itu, pembelajaran fisika lebih menekankan pada penyediaan pengalaman langsung dan berpusat pada siswa (Kurniawati, Wartono, \& Diantoro. 2014). Untuk menjadikan siswa secara mandiri dapat memahami, mengarti dan tertarik terhadap mata pelajaran Fisika siswa perlu adanya sikap ilmiah. Dengan sikap ilmiah, siswa akan dapat membentuk sikap aktif, mandiri, pola pikir kritis, logis dan terstruktur (Astalini, Kurniawan \& Sumaryanti. 2018)

Sikap merupakan salah satu faktor yang berpengaruh pada proses pembelajaran yang terdapat dalam diri siswa (Maison, Astalini, Kurniawan, \& Sholihah). Sikap adalah faktor penting yang mungkin berdampak pada pengajaran dan pembelajaran (Çener, Acun, \& Damirhan. 2015). Sikap sebagai ekspresi nilai atau pandangan hidup yang dimiliki oleh seseorang, dibentuk menjadi perilaku atau tindakan yang diinginkan (Praharesti \& Agustina, 2013). Sikap ilmiah adalah kemampuan yang konsisten, rasional, dan obyektif dalam cara tertentu menuju situasi yang bermasalah (Olasehinde \& Olatoye, 2014). Sikap ilmiah adalah aspek penting sebagai fokus selama percobaan, karena tanpa sikap ilmiah yang positif, siswa cenderung hanya menjadi pengingat konsep sains. Selain itu, kurangnya sikap sains positif juga dapat mengarah pada kecenderungan untuk mencoba memecahkan masalah, terlepas dari perilaku lingkungan alam yang merupakan konteks pembelajaran sains mereka (Zulirfan et al.,2018). Selain itu, siswa yang memiliki sikap positif terhadap fisika aktif akan terlibat dalam kelas, sedangkan siswa yang memiliki sikap negatif terlihat kurang aktif dalam keterlibatan di dalam kelas (Guido, 2013). Kegagalan dalam pencapaian pembelajaran fisika pada siswa adalah karena sikap negatif mereka dan kurangnya minat pada mata pelajaran ini (Velo, Nor, \& Khalid. 2015). Selain dengan adanya sikap ilmiah, siswa sangat memerlukan konsentrasi yang cukup jika mempelajari Fisika, karena siswa menganggap bahwa fisika itu sulit. Sehingga konsentrasi sangat diperlukan dalam pengoptimalan pembelajaran.

Konsentrasi yang dimaksud adalah untuk memusatkan perhatian pada situasi belajar yang dirancang duru sehingga semua sumber daya mental untuk belajar (Arozaq, Amin \& Muhammad. 2017). Memperhatikan dan berkonsentrasi sangat penting bagi siswa karena akan meningkatkan kompetensi dan keterampilan mereka untuk menghafal konten untuk jangka waktu yang lebih lama (Lamba, 2014). Konsentrasi belajar memiliki karakteristik yakni kemauan, dorongan, motivasi, rasa butuh, rasa ingin dan inisiatif untuk belajar, serta ini yang menyebabkan terjadinya kondisi belajar dalam diri seseorang (Lase, Marjohan, \& Syahniar. 2017). Konsentrasi itu sendiri berarti konsentrasi satu hal dengan mengesampingkan semua hal yang tidak berhubungan lainnya (Setiani, Setyowani, \& Kurniawan. 2014).

Tujuan dari penelitian ini adalah untuk melihat hubungan sikap terhadap konsentrasi belajar pada mata pelajaran fisika di SMAN 8 Kota Jambi. Dalam penelitian ini, pertanyaan yang diajukan adalah apakah terdapat hubungan antara sikap terhadap konsentrasi belajar siswa pada mata pelajaran fisika?

\section{METODE/EKSPERIMEN}

Metode yang ddigunakan dalam penelitianini adalah kuantitatif. Penelitian kuantitatif adalah penelitian yang digunakan untuk menjawab masalah melalui teknik pengukuran yang hati-hati dari variabelvariabel tertentu dengan data dalam bentuk angka dan menggunakan operasi matematika 
Tari Okta Puspitasari, Yolanda Eka Putri, dan Yohanes

untuk memfasilitasi sifat-sifatnya. Tingkat pengukuran yang digunakan dalam mengumpulkan data nominal, ordinal, interval, dan rasio merupakan faktor penting dalam memilih jenis analisis yang berlaku (Walliman , 2011 ; Shakouri \& Nazari , 2014). Metode ini berfokus pada pengumpulan data baru sesuai dengan masalah dari populasi besar dan analisis data tetapi mengabaikan emosi dan perasaan individu atau konteks lingkungan (Mackey, \& Gass , 2005).

Desain penelitian yang digunakan adalah kuantitatif asosiatif dengan jenis kolerasional. Desain korelasional adalah prosedur dalam penelitian kuantitatif di mana peneliti mengukur derajat hubungan (atau hubungan) antara dua variabel atau lebih menggunakan prosedur statistik analisis korelasional (Creswell, 2012). Tujuan dari metode ini adalah untuk mengetahui apakah terdapat hubungan antara sikap dan terhadap konsentrasi belajar siswa di SMAN 8 Kota Jambi. Teknik pengambilan sampel yang digunakan adalah purposive sampling. Penelitian ini dilakukan di SMAN 8 Kota Jambi dengan jumlah sampel 205 siswa di kelas IPA.

Instrumen penelitian yang digunakan adalah angket. Kuisioner adalah opsi yang berguna untuk dipertimbangkan ketika melakukan survei pos. Mereka bisa lebih murah daripada wawancara pribadi dan lebih cepat jika sampelnya besar dan tersebar luas. Untuk setiap survei pos terlepas dari ukuran sampel Anda harus mengizinkan setidaknya enam minggu untuk gelombang pertama kuesioner dikembalikan, dan empat minggu lagi untuk setiap pengiriman berturut-turut. Seperti halnya wawancara telepon, survei pos berguna jika responden Anda tersebar luas. Namun, karena kurangnya kontak pribadi antara responden dan peneliti, desain dan tata letak kuesioner semuanya penting (Mathers \& Amanda, 2009).

Pada penelitian ini, angket yang digunakan adalah angket adopsi dari penelitian Astalini, Kurniawan \& Darmawangsa (2018) dengan Cronbach Alpha sebesar 0,9. Angket sikap menggunakan sekala interval yangterdapat pada tabel 1 .
Tabel 1 skala interval pada sikap

\begin{tabular}{cc}
\hline Skala Likert & Rentang \\
\hline Sangat Tidak Setuju & $54.00>97.20$ \\
Tidak Setuju & $97.21>140.40$ \\
Netral & $140.41>183.60$ \\
Setuju & $183.61>226.80$ \\
Sangat Setuju & $226.81>270.00$
\end{tabular}

Sumber: Astalini, Kurniawan \& Darmawangsa (2018)

Indikator instrument angket sikap dapat ditunjukkan pada tabel 2 yaitu adalah sebagai berikut:

Tabel 2 Indikator variabel sikap

Varibel Indikator

\begin{tabular}{|c|c|}
\hline \multirow{7}{*}{ Sikap } & Implikasi sosial dari Fisika \\
\hline & Normalitas ilmuwan \\
\hline & $\begin{array}{l}\text { Sikap terhadap penyelidikan dalam } \\
\text { Fisika }\end{array}$ \\
\hline & Adopsi dari sikap ilmiah \\
\hline & Kesenangan dalam belajar Fisika \\
\hline & $\begin{array}{l}\text { Ketertarikan memperbanyak waktu } \\
\text { belajar Fisika }\end{array}$ \\
\hline & $\begin{array}{l}\text { Ketertarikan berkarir dalam bidang } \\
\text { Fisika }\end{array}$ \\
\hline
\end{tabular}

Sumber: Astalini, Kurniawan \& Darmawangsa (2018)

Sedangkan untuk indikator pada instrumen konsentrasi belajar Untuk indikator konsentrasi belajar diadopsi dari penelitian Haryadi (2017). Skala pengukuran angket yang digunakan peneliti dalam penelitian ini adalah pengukuran skala likert, dengan lima opsi (pilihan) yang dapat dipilih oleh responden, yang terdapat pada tabel 3 .

Tabel 3 skala interval pada konsentrasi belajar

\begin{tabular}{cl}
\hline Skala Likert & \multicolumn{1}{c}{ Rentang } \\
\hline Sangat Tidak Setuju & $30.00>54.00$ \\
Tidak Setuju & $54.01>78.00$ \\
Netral & $78.01>102.00$ \\
Setuju & $102.01>126.00$ \\
Sangat Setuju & $126.01>150.00$ \\
\hline
\end{tabular}

Sumber: Heryadi (2017)

Indikator variabel konsentrasi belajar terdapat pada tabel 4 yaitu sebagai berikut:

Tabel 4 Indikator Instrumen Angket Konsentrasi Belajar

\begin{tabular}{cc}
\hline Varibel & Indikator \\
\hline \multirow{3}{*}{$\begin{array}{c}\text { Konsentrasi } \\
\text { Belajar }\end{array}$} & $\begin{array}{c}\text { Fikiran dan perasaan terpadu } \\
\text { pada pelajaran }\end{array}$ \\
\cline { 2 - 2 } & $\begin{array}{c}\text { Perhatian tidak menyebar } \\
\text { Mampu mengabaikan hal-hal } \\
\text { lain yang tidak ada } \\
\text { hubungannya dengan belajar }\end{array}$ \\
\cline { 2 - 2 } & Tidak terpengaruh dengan hal- \\
\hline
\end{tabular}




\begin{tabular}{|c|c|}
\hline \multirow[t]{2}{*}{ Varibel } & Indikator \\
\hline & $\begin{array}{c}\text { hal lain yang tidak ada } \\
\text { hubungannya dengan proses } \\
\text { belajar } \\
\text { Antusias belajar tinggi } \\
\begin{array}{c}\text { Mampu memusatkan perhatian } \\
\text { dalam waktuyang lama }\end{array} \\
\end{array}$ \\
\hline $\begin{array}{l}\text { Sumber: Heryadi } \\
\text { Teknik an } \\
\text { adalan statisti } \\
\text { inferensial. Pac } \\
\text { digunakan berup } \\
\text { Sedangkan sta } \\
\text { kolerasioanl. } \\
\text { menyajikan tabe } \\
\text { konsentrasi bel } \\
\text { tingkat hubungg } \\
\text { Tabel } 5 \text { Rentang }\end{array}$ & $\begin{array}{l}\text { (2017) } \\
\text { nalisis data yang digunakan } \\
\text { ic deskriptif dan statistic } \\
\text { da statistik deskriptif yang } \\
\text { pa mean, median dan mode } \\
\text { atistic inferensial digunakan } \\
\text { Data analisis inferensia } \\
\text { el hubungan sikap terhadap } \\
\text { lajar siswa, dengan rentang } \\
\text { an terdapat pada tabel } 5 \text {. } \\
\text { g Tingkat Hubungan (Korelasi ) }\end{array}$ \\
\hline Interval Koefisien & n Rentang Tingkat Hubungan \\
\hline $0,80>1.000$ & Sangat kuat \\
\hline $0,60>0,799$ & Kuat \\
\hline $0,40>0,599$ & Cukup \\
\hline $0,20>0,399$ & Lemah \\
\hline $0,00>0,199$ & Sangat lemah \\
\hline
\end{tabular}

\section{HASIL DAN PEMBAHASAN}

Keterbaruan dari penelitian ini adalah variabel yang digunakan dalam menentukan hubungan antara sikap dan konsentrasi belajar siswa pada mat pelajaran fisika di SMAN 8 Kota Jambi. Dengan variabel yang digunakan adalah sikap dan konsentrasi belajar.

\section{HASIL}

sikap terbentuk dengan adanya sebuah pengalaman langsung dalam pribadi maupun secara sosial yang telah dipelajari maupun dibentuk secara alami. Sikap siswa di SMAN 8 Kota Jambi dapat dilihat melalui data yang terdapat pada tabel 6 .
Pada tabel 6 terdapat hasil dari statistic deskriptif variabel sikap. Pada tabel tersebut terdapat jumlah total responden yang digunakan adalah 177. Dari hasil tersebut dapat dikatakan bahwa sikap siswa yang ada di SMAN 8 Kota Jambi dominan cukup baik. Sedangkan konsentrasi belajar pada mata pelajaran fisika di Sekolah Menengah Atas Negeri 8 Kota Jambi dapat dilihat pada tabel 7.

Berdasarkan hasil dari tabel 5 yaitu konsentrasi belajar dengan kategori cukup adalah yang paling dominan dengan jumlah 155 dari 177 responden, yang menghasilkan persentase $65.6 \%$. Oleh sebab itu, dalam variabel konsentrasi belajar, siswa di Sekolah Menengah Atas Negeri 8 Kota Jambi memiliki kategori cukup baik.

\section{Uji Kolerasi}

Setelah mengetahui analisis data dari variabel sikap dan konsentrasi belajar siswa di Sekolah Menengah Atas Negeri 8 Kota Jambi, langkah selanjutnya adalah mengetahui hubungan sikap terhadap konsentrasi belajar pada mata pelajarn fisika. Hasil analisis hubungan kedua variabel tersebut dapat dilihat pada tabel 8

Tabel 8 hubungan antara sikap terhadap konsentrasi belajar siswa di Sekolah Menengah Atas Negeri 8 Kota Jambi

\begin{tabular}{llrr}
\hline & & Sikap & Konsentrasi \\
\hline Sikap & $\begin{array}{l}\text { Pearson } \\
\text { Correlation }\end{array}$ & 1 & 0.155 \\
Sig. (2- & & 0.03 \\
Konsentrasi & $\begin{array}{l}\text { tailed) } \\
\text { Pearson } \\
\text { Correlation } \\
\text { Sig. (2- } \\
\text { tailed) }\end{array}$ & 0.155 & 1 \\
& 0.04 & \\
\hline
\end{tabular}

Pada tabel 6 yaitu hubungan sikap terhadap konsentrasi belajar siswa pada mata pelajaran fisika di SMAN 8 Kota Jambi memiliki hubungan

Tabel 6 statistik deskriptif dari variabel sikap siswa di Sekolah Menengah Atas Negeri 8 Kota Jambi

\begin{tabular}{|c|c|c|c|c|c|c|c|c|}
\hline \multicolumn{9}{|c|}{ Klasifikasi } \\
\hline Rentang & Kategori & Total & $\%$ & Mean & Median & Mode & Min & Maks \\
\hline $54.0-97.20$ & Sangat tidak baik & 0 & 0 & & & & & \\
\hline $97.21-140.40$ & Tidak baik & 8 & 4.5 & & & & & \\
\hline $140.41-183.60$ & Cukup & 99 & 55.9 & 3.3559 & 3.0000 & 3.00 & 2.00 & 5.00 \\
\hline $183.61-226.80$ & Baik & 69 & 39.0 & & & & & \\
\hline $226.81-270.00$ & Baik sekali & 1 & 0.6 & & & & & \\
\hline
\end{tabular}


Tabel 7 statistik deskriptif dari variabel konsentrasi belajar siswa di Sekolah Menengah Atas Negeri 8

\begin{tabular}{|c|c|c|c|c|c|c|c|c|}
\hline \multicolumn{9}{|c|}{ Klasifikasi } \\
\hline Rentang & Kategori & Total & $\%$ & Mean & Median & Mode & Min & Maks \\
\hline $30.00>54.00$ & Sangat tidak baik & 0 & 0 & & & & & \\
\hline $54.01>78.00$ & Tidak baik & 5 & 2.8 & & & & & \\
\hline $78.01>102.00$ & Cukup & 155 & 65.5 & 3.3051 & 3.0000 & 3.00 & 2.00 & 5.00 \\
\hline $102.01>126.00$ & Baik & 53 & 29.9 & & & & & \\
\hline $126.01>150.00$ & Baik sekali & 3 & 1.7 & & & & & \\
\hline
\end{tabular}

yang signifikan. Dimana hubungan antara sikap dan konsentrasi belajar dikategorikan kuat karena nilai sig yang dihasilkan adalah 0,04. Sehingga dapat dikatakan bahwa hubungan antara sikap terhadap konsentrasi belajar fisika pada mata pelajaran fisika dalam kategori kuat dan cukup memadai.

\section{PEMBAHASAN}

Sikap adalah pandangan atau perasaan positif atau negatif disertai dengan kecenderungan untuk bertindak pada objek tertentu (Hardiyanti, astalini \& Kurniawan. 2018). Sikap dan minat positif terhadap fisika sangat berpengaruh terhadap proses pembelajaran (Astalini, Kurniawan, Perdana, \& Kurniasari. 2018). Sikap seorang siswa menentukan keberhasilan materi yang diserap dalam proses pembelajaran (Astalini, Kurniawan, Melsayanti, \& Destianti. 2018).

Sikap siswa dapat berdampak pada konsentrasi belajar siswa. Konsentrasi adalah konsentrasi perhatian dalam proses perubahan perilaku yang dinyatakan dalam bentuk penguasaan, penggunaan, dan penilaian sikap dan nilai-nilai, pengetahuan dan keterampilan dasar yang ditemukan di berbagai bidang studi ( Aviana \& Hidayah , 2015).

Konsentrasi belajar dapat dikatakan baik jika sikap siswa baik. Sehingga akan menghasilkan kegiatan yang berkualitas. Seseorang dapat belajar dengan baik apabila orang tersebut dapat berkonsentrasi dengan baik, dengan kata lain mampu memusatkan pikiran (Dahlia,2017).

Semakin tinggi konsentrasi pengajar dan pelajar, semakin efektif kegiatan pembelajaran tersebut, namun sebaliknya jika konsentrasi siswa rendah maka hasil yang diperolehnya pun tidak maksimal (Halil, Yanis \& Noer, 2015). Biasanya konsentrasi siswa akan menurun saat jam pelajaran terakhir yang disebabkan karena kondisi kelas yang panas, rasa lapar, dan kantuk (Aviana \& Hidayah, 2015). Saat berkonsentrasi, pikiran tidak boleh dibiarkan menyebar. Ini akan menyebabkan konsentrasi belajar siswa akan memudar dan terganggu

\section{PENUTUP}

Berdasarkan penelitian yang telah dilakukan, dapat disimpulkan bahwa terdapat hubungan antara sikap terhadap konsentrasi belajar siswa pada mata pelajaran fisika di SMAN 8 Kota Jambi. Adanya hubungan tersebut dapat dikatakan cukup kuat, ditandai dengan besar sig yang diperoleh pada uji kolerasioanal yaitu sebesar 0.04 .

\section{UCAPAN TERIMAKASIH}

Terimaksih kepada Kepada Kepala Sekolah dan Guru SMAN 8 Kota Jambi, serta kepada responden yang telah membantu dalam penelitian ini

\section{REFERENSI}

Arozaq, M., Amin, \& Muhammad, A. . (2017). Implementation of Reading Guide Strategy in Global Climate Change Material for Enhancement of Student Learning Outcome. International Journal of Active Learning, 2(2), 82-89.

https://doi.org/https://doi.org/10.15294/ijal.v2i $\underline{2.10803}$

Astalini, A., Kurniawan, D. A., Melsayanti, R., \& Destianti, A. (2018). SIKAP TERHADAP MATA PELAJARAN IPA DI SMP seKABUPATEN MUARO JAMBI. Lentera Pendidikan: Jurnal IImu Tarbiyah Dan Keguruan, 21(2), 214. https://doi.org/10.24252/lp.2018v21n2i7 
Astalini, Kurniawan, D.A, \& Sumaryanti. (2018). Sikap Siswa Terhadap Pelajaran Fisika Di SMAN Kabupaten Batanghari. Jurnla ilmu pendidikan fisika, 3(2), 59-64

Astalini, Kurniawan., D., A, Darmawangsario., R. (2018). Pengembangan Instrument Sikap Siswa Sekolah Menengah Atas Terhadap Mata Pelajaran Fisika. JPF: jurnal pendidikan fisika, 6 (1), 107-114

Aviana Ria Dan Hidayah Fitria Fatichatul. (2015). 'Pengaruh Tingkat Konsentrasi Belajar Siswa Terhadap Daya Pemahaman Materi Pada Pembelajaran Kimia Di Sma Negeri 2 Batang'. Jurnal Pendidikan Sains. 3(1)

Çener, E., Acun, İ., \& Demirhan, G. (2015). The Impact of ICT on Pupils' Achievement and Attitudes in Social Studies. Journal of Social Studies Education Research, 6(1), 190-207. https://doi.org/10.17499/jsser.67856

Creswell, JohnW. (2012). Educational Research Planning, Conducting and evaluating quantitative dan qualitative research. Lincoln: University of Nebraska

Dahlia. (2017). 'Meningkatkan Konsentrasi Belajar Siswa Dalam Pembelajaran Matematika Melalui Model Pembelajaran Numbered Heads Together (NHT) di Kelas VII.2 SMP Negeri 1 Barru'. J. Saintifik@ MIPA. 1(1), ISSN: 2087-3816

Gougoulakis, P. (2017). Educating Scientists Philosophy and Practice of University Pedagogy. Academia journal,35-75.

Guido, R. D. (2013). Attitude and Motivation towards Learning Physics. International Journal of Engineering Research \& Technology (IJERT), 2(2), 1-19.

Halil, A., Yanis, A., \& Noer, M. (2015). 'Pengaruh Kebisingan Lalulintas Terhadap Konsentrasi
Belajar Siswa SMP N 1 Padang'. Jurnal Kesehatan Andalas. 4(1)

Hanafy, M., S. 2014. Konsep Belajar dan Pembelajaran. Lentera Pendidikan. 17(1), 66-79

Hardiyanti, K., Astalini, A., \& Kurniawan, D. A. (2018). Sikap Siswa Terhadap Mata Pelajaran Fisika Di Sma Negeri 5 Muaro Jambi. EduFisika, 3(02), 1-12. https://doi.org/10.22437/edufisika.v3i02.45 $\underline{22}$

Haryadi, Herjan. (2017). 'Efektivitas Strategi Pengajaran Edutaimenr Dengan Metode Picture And Picture Terhadap Konsentrasi Belajar Metematika Materi Pokok Himpunan Pada Siswa Kelas VII Mts. Darussalam Bermi Tahun Pelajaran 2016/2017'. jurnal Imiah Mandala Education. 3(2), ISSN: 2442-9511

Hubert, V. (2014). students will learn to increase their knowledge and knowledge to get education that is in accordance with existing standards. Academia journal. 4(1)

Kurniawan, D. A., Perdana, R., \& Kurniasari, D. (2018). Identification of Student Attitudes toward Physics Learning at Batanghari District High School. The Educational Review, USA, 2(9), 475-484. https://doi.org/10.26855/er.2018.09.003

Kurniawati, I. D., Wartono, \& Diantoro, M. (2014). Pengaruh Pembelajaran Inkuiri Terbimbing Integrasi Peer Instruction Terhadap Penguasaan Konsep dan Kemampuan Berpikir Kritis Siswa. Jurnal Pendidikan Fisika Indonesia, 10(1), 36-46.

https://doi.org/10.15294/jpfi.v10i1.3049

Lamba, M. S. (2014). Impact of Teaching Time on Attention and Concentration. IOSR Journal of Nursing and Health Science, 3(4), 01-04. https://doi.org/10.9790/1959-03410104 
Tari Okta Puspitasari, Yolanda Eka Putri, dan Yohanes

Mackey, Alison and Gass Susan M. (2005). Second Language Research Methodology And Design. London: Lawrence Erlbaum Associates

Maison, Astalini, Kurniawan., D., A, \& Sholihah., L., R. (2018). Deskripsi Sikap Siswa SMA Negeri pad Mata Pelajaran Fisika. Edusains. 10(1), 160-167

Mathers Nigel \& Hunn Amanda. (2009). Surveys And Questionnaires. National Instutude For Health Research: East Midlands

Praharesti Eriany \& Agustina Jaya. (2013). FaktorFaktor Yang Mempengaruhi Motivasi Ibu Menyekolahkan Anak di Homeschooling kak Seto Semarang. Jurnal Psikodimensia, 12(1), 47-62

Pratama, D. S., Ermawaty, I. R., \& Hartini, T. I. (2017). Hubungan Antara Adversity Quotient dan Self Efficacy dengan Menggunakan Model PBL Terhadap Hasil Belajar Fisika Siswa SMA. JIPFRI (Jurnal Inovasi Pendidikan Fisika Dan Riset IImiah), 1(2), 8893. https://doi.org/10.30599/jipfri.v1i2.117

Şener, N., Türk, C., \& Taş, E. (2015). Improving Science Attitude and Creative Thinking through Science Education Project: A Design, Implementation and Assessment. Journal of Education and Training Studies, 3(4), 57-67. https://doi.org/10.11114/jets.v3i4.771

Shakouri, N., \& Nazari, O. (2014). Qualitative research: Incredulity toward meta narrativeness. Journal of Education and Human Development, 3(2), 671-680.

Siswanto, Kaniawati , I., \& Suhandi, A. (2014). Penerapan Model Pembelajaran Pembangkit Argumen Menggunakan Metode Saintifik Untuk Meningkatkan Kemampuan Kognitif Dan Keterampilan Berargumentasi Siswa. Jurnal Pendidikan Fisika Indonesia (JPFI), 10(2),

104-116.

http://doi.org/10.15294/jpfi.v10i2.3347
Susilawati, A., Hernani, H., \& Sinaga, P. (2017). the Application of Project-Based Learning Using Mind Maps To Improve Students' Environmental Attitudes Towards Waste Management in Junior High Schools. International Journal of Education, 9(2), 120. https://doi.org/10.17509/ije.v9i2.5466

Velo, A., Nor, R., \& Khalid, R. (2015). Attitude towards physics and additional mathematics achievement towards physics achievement. International Education Studies, 8(3), 35-43. https://doi.org/10.5539/ies.v8n35

Walliman, N. (2011). Research Methods. London : Routledge 